\title{
Glial Cell Line-Derived Neurotrophic Factor Expression in Skin Alters the Mechanical Sensitivity of Cutaneous Nociceptors
}

\author{
Kathryn M. Albers, ${ }^{1}$ C. Jeffrey Woodbury, ${ }^{2}$ Amy M. Ritter, ${ }^{2}$ Brian M. Davis, ${ }^{1}$ and H. Richard Koerber ${ }^{2}$ \\ Departments of ${ }^{1}$ Medicine and ${ }^{2}$ Neurobiology, University of Pittsburgh School of Medicine, Pittsburgh, Pennsylvania 15261
}

\begin{abstract}
Neurons classified as nociceptors are dependent on nerve growth factor (NGF) during embryonic development, but a large subpopulation lose this dependence during embryonic and postnatal times and become responsive to the transforming growth factor $\beta$ family member, glial cell line-derived growth factor (GDNF). To elucidate the functional properties of GDNF-dependent nociceptors and distinguish them from nociceptors that retain NGF dependence, the cellular and physiologic properties of sensory neurons of wild-type and transgenic mice that overexpress GDNF in the skin (GDNF-OE) were analyzed using a skin, nerve, dorsal root ganglion, and spinal cord preparation, immunolabeling, and reverse transcriptase-PCR assays. Although an increase in peripheral conduction velocity of C-fibers in GDNF-OE mice was measured, other electrophysiological properties, including resting membrane potential and somal action potentials, were unchanged. We also show that isolectin B4 (IB4)-positive neurons, many of which are responsive to GDNF, exhibited significantly lower thresholds to mechanical stimulation relative to wild-type neurons. However, no change was observed in heat thresholds for the same population of cells. The increase in mechanical sensitivity was found to correlate with significant increases in acid-sensing ion channels $2 \mathrm{~A}$ and $2 \mathrm{~B}$ and transient receptor potential channel $\mathrm{Al}$, which are thought to contribute to detection of mechanical stimuli. These data indicate that enhanced expression of GDNF in the skin can change mechanical sensitivity of IB4-positive nociceptive afferents and that this may occur through enhanced expression of specific types of channel proteins.
\end{abstract}

Key words: nociceptor; C-fiber; GDNF expression; sensory neuron; TRPV; channel

\section{Introduction}

During development, the survival of most cutaneous sensory neurons is dependent on the neurotrophin NGF (Crowley et al., 1994; Koltzenburg, 1999). NGF-dependent neurons are small to medium in size, express neuropeptides, the trkA receptor protein, and have nociceptor-like response properties (Rice et al., 1998; Mendell et al., 1999). NGF-responsive afferents are either lightly myelinated high-threshold mechanoreceptors (HTMRs) or unmyelinated (C-fibers) and project to dermal and epidermal layers of the skin and superficial dorsal horn of the spinal cord (Light and Perl, 1979; Sugiura et al., 1986, 1989). At late embryonic and postnatal times, the dependency on NGF for many cutaneous neurons is decreased. These neurons begin to express the receptor tyrosine kinase Ret and become responsive to growth factors in the glial cell line-derived neurotrophic factor (GDNF) family (Molliver and Snider, 1997; Molliver et al., 1997; Baloh et al., 2000; Airaksinen and Saarma, 2002). Neurons that are ini-

\footnotetext{
Received Feb. 7, 2005; revised Feb. 3, 2006; accepted Feb. 4, 2006.

This work was supported by National Institutes of Health Grants NS23725 (H.R.K.), NS31826 (B.M.D.), and NS/GM33730 (K.M.A.). We thank Dr. R. Elde (University of Minnesota, Minneapolis, MN) for providing the P2X antibody.

Correspondence should be addressed to H. Richard Koerber, Department of Neurobiology, University of Pittsburgh, School of Medicine, Pittsburgh, PA 15261. E-mail: rkoerber@pitt.edu.

C. J. Woodbury's present address: Department of Zoology and Physiology, University of Wyoming, Laramie, WY 82071.

A. M. Ritter's present address: Department of Pharmacology, Merck and Company, 126 East Lincoln Avenue R80Y-140, Rahway, NJ 06075.

DOI:10.1523/JNEUROSCI.4863-05.2006

Copyright $\odot 2006$ Society for Neuroscience $\quad$ 0270-6474/06/262981-10\$15.00/0
}

tially trkA positive that switch dependency to GDNF are typically small- to medium-sized neurons that express growth factor receptor $\alpha 1$ (GFR $\alpha 1$ ), are peptide poor, and bind isolectin B4 (IB4) (Silverman and Kruger, 1988; Molliver et al., 1997; Bennett et al., 1998). Centrally, these fibers project to spinal cord lamina II, with some projections to lamina I in a variety of species, including adult mouse (Kitchener et al., 1993; Woodbury et al., 2000; Gerke and Plenderleith, 2001; Woodbury et al., 2004).

To identify the properties of the GDNF-dependent sensory population and their role in pain signaling, we generated transgenic mice that overexpress GDNF (GDNF-OE) in skin (Zwick et al., 2002). GDNF overexpression increased the number of dorsal root ganglion (DRG) neurons by $27 \%$, almost the reverse of the number of DRG neurons lost in postnatal (day 0) $\mathrm{GDNF}^{-/-}$ animals (Moore et al., 1996). Immunohistochemical analysis showed that this increase was in IB4-positive neurons and also resulted in increased purinergic $\mathrm{P}_{2} \mathrm{X}_{3}$-positive cutaneous fibers (Zwick et al., 2002).

Phenotypic differences between GDNF- and NGF-dependent C-fibers suggest that they represent different types of nociceptive neurons with distinct functional properties (Snider and McMahon, 1998). These properties may underlie, at least in part, different types of persistent pain and changes in physiology, gene expression, and anatomy that accompany injury. Studies of transgenic mice that overexpress NGF in the skin showed significant changes in functional properties of unmyelinated nociceptive fibers, most notably a fourfold increase in firing frequency in response to heat stimuli (Stucky et al., 1999). Response properties 
of neurons expressing IB4 have also been examined (Fjell et al., 1999; Stucky and Lewin, 1999; Dirajlal et al., 2003; Woodbury et al., 2004). In vitro, IB4-positive neurons had broader action potentials (APs) and smaller heat-activated currents than IB4negative neurons (Stucky and Lewin, 1999). In an ex vivo preparation, IB4-positive neurons were frequently characterized as polymodal nociceptors (Woodbury et al., 2004). In the current study, we used this ex vivo preparation to examine whether response properties of IB4 neurons are modulated in GDNF-OE mice. In addition, assays to measure expression of channel proteins associated with heat and mechanical sensitivity in GDNF-OE mice were performed.

\section{Materials and Methods}

\section{Transgenic mice}

A transgene containing $2.3 \mathrm{kbp}$ of the human K14 keratin promoter (Albers et al., 1994), the mouse GDNF cDNA (Springer et al., 1995), and intron/exon splice sites and poly $\left(\mathrm{A}^{+}\right)$signal from the human growth hormone gene were used to isolate GDNF-OE transgenic mice (line 097). Details concerning the isolation of this transgenic line have been described by Zwick et al. (2002). GDNF-OE mice are on a C3H $\times$ B6 F1 hybrid genetic background and express a sixfold and fourfold increase in GDNF protein in the skin and DRG, respectively. Male and female mice at 3-6 months of age were used in these studies. Mice were housed in group cages, were maintained on a $12 \mathrm{~h}$ light/dark cycle in a temperaturecontrolled environment $\left(20.5^{\circ} \mathrm{C}\right)$, and were given food and water ad libitum. These studies were performed in accordance with the guidelines of the Institutional Animal Care and Use Committee at the University of Pittsburgh and the National Institutes of Health Guide for the Care and Use of Laboratory Animals. Except for supportive data on C-lowthreshold mechanoreceptors (CLTMRs) from three Swiss Webster mice, all data reported are from mice on the $\mathrm{C} 3 \mathrm{H} / \mathrm{B} 6$ hybrid background.

\section{Immunocytochemistry}

For single-cell immunohistochemistry, DRG containing the Neurobiotin (NB)-labeled somata of identified afferent fibers were fixed $1 \mathrm{~h}$ in $4 \%$ paraformaldehyde, embedded in gelatin, placed in fix for $1 \mathrm{~h}$, and sunk in $25 \%$ sucrose $/ 0.1 \mathrm{M}$ phosphate buffer. Frozen sections were cut using a sliding microtome set at $25 \mu \mathrm{m}$. Sections were incubated overnight with tetramethylrhodamine isothiocyanate (TRITC)-conjugated Bandeiraea simplicifolia isolectin (BSI) (1:100; Sigma, St. Louis, MO) or FITCconjugated IB4 (1:100; Sigma) and antisera for either $\mathrm{P}_{2} \mathrm{X}_{3}(1: 1000)$ (Guo et al., 1999) or calcitonin gene-related peptide (CGRP) (1:1000; Chemicon, Temecula, CA). We double labeled mouse DRG sections and found 100\% overlap between TRITC-BSI and FITC-IB4 (B. M. Davis and M. Zwick, unpublished observations); thus, for simplicity, we will refer to IB4 labeling throughout the remainder of the manuscript. Sections were washed, incubated in anti-rabbit IgG-cyanine 2 (Cy2) or IgG-Cy3 (1:200; Jackson ImmunoResearch, West Grove, PA), and FITC-avidin or TRITC-avidin to visualize the stained cell. These sections were then analyzed using a Leica (Nussloch, Germany) confocal microscope. Confocal analysis consisted of taking sequential scans (FITC, Cy3, and Cy5) of single optical sections.

To examine the relative levels of acid-sensing ion channel 2 (ASIC2) immunostaining, two thoracic ganglia from four sets of wild-type (WT) and GDNF-OE mice (eight mice total) were embedded side by side in a single gelatin block. Frozen sections $(50 \mu \mathrm{m})$ containing both ganglia were incubated overnight with ASIC2 antibody (diluted 1:1000; Chemicon, Temecula, CA), followed by a $1 \mathrm{~h}$ incubation with goat anti-rabbit IgG-Cy5 conjugate. Sections were then incubated with IB4-TRITC for $1 \mathrm{~h}$, followed by washes in phosphate buffer. Thus, wild-type and transgenic sections were exposed to the same solutions during the incubation process. Binding was visualized using an Olympus Optical (Thornwood, NY) confocal microscope, and comparisons were made between WT and GDNF-OE tissue contained in the same gelatin section.

\section{Electrophysiology}

Ex vivo preparation. A skin, nerve, DRG, and spinal preparation was used to examine individual sensory neurons in WT and GDNF-OE mice
(Woodbury et al., 2001; Koerber and Woodbury, 2002). Adult mice were anesthetized with an intramuscular injection of a mix of ketamine $(90$ $\mathrm{mg} / \mathrm{kg})$ and xylazine $(10 \mathrm{mg} / \mathrm{kg})$. Animals were perfused transcardially through the left ventricle with chilled $\left(14^{\circ} \mathrm{C}\right)$ and oxygenated $(95 \%$ $\mathrm{O}_{2}-5 \% \mathrm{CO}_{2}$ ) artificial CSF (aCSF) in which most sodium cations had been replaced with sucrose (in mM: 253.9 sucrose, $1.9 \mathrm{KCl}, 1.2 \mathrm{KH}_{2} \mathrm{PO}_{4}$, $1.3 \mathrm{MgSO}_{4}, 2.4 \mathrm{CaCl}_{2}, 26.0 \mathrm{NaHCO}_{3}$, and $10.0 \mathrm{D}$-glucose). The spinal cord and the right body wall were excised and placed in a circulating bath of the same solution. The spinal cord was hemisected, and up to 10 contiguous dorsal cutaneous nerves (DCNs), along with a longitudinal rectangular patch of dorsolateral skin, was dissected in continuity with their DRGs. This produces an isolated preparation with spinal cord, DRGs, nerves, and skin intact that was transferred to a recording chamber containing oxygenated aCSF in which the sodium was replaced. The aCSF was then slowly warmed to $31^{\circ} \mathrm{C}$. The skin was pinned out on a mesh-covered platform. The level of the bath was lowered so that the epidermis was at the surface exposed to air. Somata in lower thoracic DRG were impaled using electrodes filled with 15-20\% NB (Vector Laboratories, Burlingame, $\mathrm{CA}$ ) in $1 \mathrm{~m} \mathrm{~K}$-acetate. Cells were identified as innervating the patch of skin by electrical stimulation of the appropriate DCN using an en passant suction electrode. The conduction delay of the cell was recorded, and, using the distance from the stimulating electrode to the DRG, the conduction velocity of the cell was calculated. Cells with peripheral fiber conduction velocities $<1.0 \mathrm{~m} / \mathrm{s}$ were classified as C-fiber afferents. The peripheral response properties of the cell, first to mechanical and then thermal stimuli, were assessed using a fine sable-hair paintbrush, blunt glass stylus, hand-held calibrated von Frey filaments (Stoelting, Wood Dale, IL), computer-controlled Peltier device, and, on occasion, by applying dilute acid $(0.2 \mathrm{M} \mathrm{HCl})$ to its receptive field. Thermal stimulation consisted of first rapidly cooling the skin from 31 to $4^{\circ} \mathrm{C}$ and then heating the skin from 31 to 48 or $50^{\circ} \mathrm{C}$. The temperature was held at 48 or $50^{\circ} \mathrm{C}$ for $5 \mathrm{~s}$ and then quickly cooled back to bath temperature. The average firing rate during this $5 \mathrm{~s}$ plateau was used as a measure of heat responsiveness. The Peltier had relatively small footprint $(3 \times 5$ $\mathrm{mm}$ ), reducing the potential problem of heating the same area of skin multiple times. This potential problem was also minimized by the fact that cells in different DRGs were analyzed, reducing the possible overlap of receptive fields. The temperature was monitored by a thermocouple placed between the Peltier element and the skin. After characterization, the cell was iontophoretically injected with NB, and the DRG was removed and processed for immunochemical labeling.

Skin-nerve preparation. Adult WT and GDNF-OE mice were anesthetized and perfused using the same anesthetics and solutions as stated above for the ex vivo preparation. The same patch of back skin and individual DCNs were dissected free and placed in a circulating bath containing the same oxygenated aCSF maintained at $31^{\circ} \mathrm{C}$. The skin was placed on a mesh-covered platform with the epidermal side up. A small plastic well containing a platinum hook electrode in a pool of mineral oil was placed at the surface of the circulating bath. Individual nerves were desheathed, and fine strands of fibers were dissected free and placed in contact with the platinum hook electrode. Individual C-fiber response properties were assessed as described above. Conduction velocities in this preparation were determined by electrical stimulation of the receptive field of the fiber using a concentric metal electrode. The distance between the location of the stimulation site and the recording electrode was used to calculate the conduction velocity of these fibers. C-fibers were classified as having conduction velocities of $<1.0 \mathrm{~m} / \mathrm{s}$.

\section{Reverse transcriptase-PCR analysis}

RNA was extracted from pooled lumbar (L3/L4/L5) DRG of individual mice. Mice were deeply anesthetized by injection of Avertin (2-2-2 tribromoethanol in tert-amyl alcohol) anesthetic and then transcardially perfused with $\sim 75 \mathrm{ml}$ of ice-cold phosphate buffer. DRGs were collected on dry ice and stored at $-80^{\circ} \mathrm{C}$ until RNA extraction. RNA was isolated by homogenizing tissue in $1 \mathrm{ml}$ of Trizol reagent (Invitrogen, Carlsbad, CA), followed by isopropanol precipitation. Pellets were washed with $70 \%$ ethanol and suspended in RNase-free water, and the concentration was determined using a GeneQuant RNA/DNA calculator (Amersham Biosciences, Piscataway, NJ). RNA $(5 \mu \mathrm{g})$ was treated with DNase (In- 
Table 1. List of primer pairs used for PCR gene amplification

\begin{tabular}{|c|c|}
\hline Gene & Primer set $5^{\prime} \rightarrow 3^{\prime}$ \\
\hline \multirow[t]{2}{*}{ TRPV1 } & TTCCTGCAGAAGAGCAAGAAGC \\
\hline & CCCATTGTGCAGATTGAGCAT \\
\hline \multirow[t]{2}{*}{ TRPV2 } & TGACTCGGCATACACAGAAGGCTC \\
\hline & TTGACAAGGGGCTGAGGATTGC \\
\hline \multirow[t]{2}{*}{ TRPV3 } & CCTGGAGATAGAAGGATTTGAGCC \\
\hline & TGTTGGGATTGGATGGGGTC \\
\hline \multirow[t]{2}{*}{ TRPV4 } & TGGATTCCTTGTTCGACTACGG \\
\hline & CACAATGTCAAAGAGGATGGGC \\
\hline \multirow[t]{2}{*}{ ASIC1 } & CTGGACTTCCTAGTGGAGAA \\
\hline & CCAGCACCAGAATATTCTCC \\
\hline \multirow[t]{2}{*}{ ASIC2a } & ATGGACCTCAAGGAGAGCCCCAG \\
\hline & AAGTCTTGATGCCCACACTCCTGC \\
\hline \multirow[t]{2}{*}{ ASIC2b } & CGCACAACTTCTCCTCAGTGTTTAC \\
\hline & TTGGATGAAAGGTGGCTCAGAC \\
\hline \multirow[t]{2}{*}{ ASIC3 } & ATGAAACCTCCCTCAGGACTGG \\
\hline & AACTCCCCATAGTAGCGAACCC \\
\hline \multirow[t]{2}{*}{ TRPM8 } & TCTCACCAATGAAGTCCTCACAGAG \\
\hline & TTCCACATCCAAGTCCTCCCTG \\
\hline \multirow[t]{2}{*}{ TRPA1 } & TTCCAAGATGCCTTCAGCACC \\
\hline & ACCGCCAAGCCAATCAGTAAG \\
\hline \multirow[t]{2}{*}{ GAPDH } & ATGTGTCCGTCGTGGATCTGA \\
\hline & GCTGTTGAAGTCGCAGGAGACA \\
\hline
\end{tabular}

a.

\section{C-polymodal nociceptor}

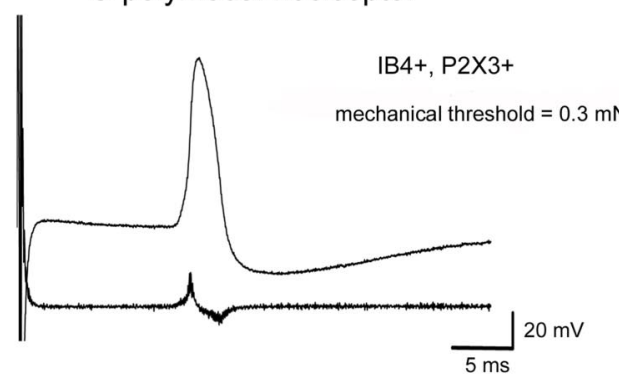

C.

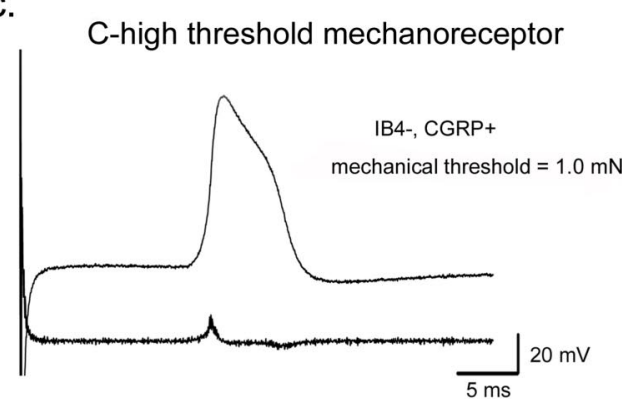

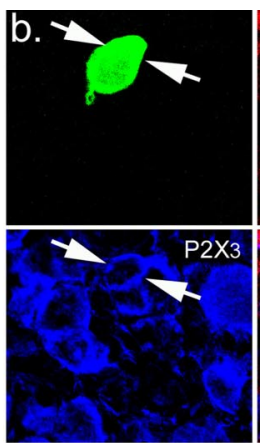

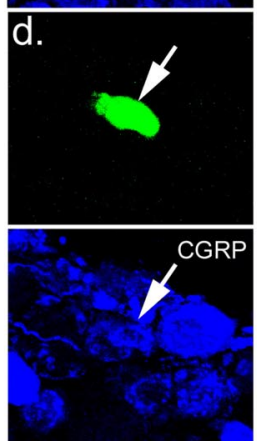

mixtures provided in the SYBR green reagent kit (Applied Biosystems). The amplification protocol included $2 \mathrm{~min}$ at $50^{\circ} \mathrm{C}$ to activate the AmpErase UNG to prevent the reamplification of any carryover PCR products, $12 \mathrm{~min}$ at $95^{\circ} \mathrm{C}$ to activate the Amplitaq polymerase, 40 cycles of $15 \mathrm{~s}$ at $95^{\circ} \mathrm{C}$ for denaturation, and $1 \mathrm{~min}$ at $60^{\circ} \mathrm{C}$ for annealing and extension. After amplification, a dissociation curve was plotted against melting temperature to ensure amplification of a single product and to test for primer dimers. Controls were run with water replacing the template (to further test for primer dimers). Relative fold change in RNA level was calculated by the threshold cycle $\left(\mathrm{C}_{\mathrm{T}}\right)$ method using glyceraldehyde-3-phosphate dehydrogenase (GAPDH) as a reference standard because its level of expression was identical to that of the GDNF-OE ganglia. $\mathrm{C}_{\mathrm{T}}$ values from triplicate samples were averaged and subtracted from the reference standard yielding $\Delta \mathrm{C}_{\mathrm{T}}$. The difference between the $\Delta \mathrm{C}_{\mathrm{T}}$ of the experimental and control groups was then calculated $\left(\Delta \mathrm{C}_{\mathrm{T}}\right)$. The relative fold change was determined as $2^{-\Delta C T}$. An unpaired $t$ test $(p \leq 0.05)$ was used to determine significance of expression. PCR primers for real-time PCR analysis (Table 1) were generated using Primer Express software (Applied Biosystems) using parameters optimized by the manufacturer. For all other gene targets, PCR reactions were done in the presence of $\left[{ }^{32} \mathrm{P}\right] \mathrm{dCTP}$. The cycle number was optimized for each set of primers by first running PCR reactions at different cycle numbers to establish the midphase of the reaction. Aliquots of the optimized PCR reaction were run on $8 \%$ polyacrylamide gels in Tris borate EDTA buffer, gels were dried and placed against a PhosphorImager screen, and the relative level of incorporated $\left[{ }^{32} \mathrm{P}\right] \mathrm{dCTP}$ was determined using a Bio-Rad (Hercules, CA) PhosphorImager. Values were normalized to GAPDH. Primer sets used in radioactively labeled reactions were generated using Macvector software (Accelrys, San Diego, CA).

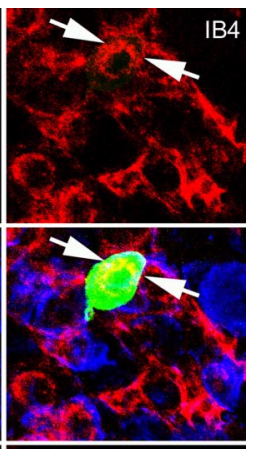

\section{Results}

Effects of GDNF-OE on somal action potential properties

To determine whether enhanced levels of skin-derived GDNF affected physiologic properties of C-fiber afferents, we recorded intracellularly from a total of 25 C-fiber somata in preparations from eight WT mice and 37 C-fiber somata from eight GDNF-OE mice. Of these fibers, 19 from WT and 28 from GDNF-OE preparations showed stable resting membrane potentials of $-50 \mathrm{mV}$ or lower and displayed AP overshoot. The somal action potentials of these fibers were used for additional analysis (Fig. 1). The average resting membrane potentials of the two groups was $62.1 \pm 2.3 \mathrm{mV}$ in GDNF-OE mice and $59.6 \pm 1.9 \mathrm{mV}$ in WT mice. The somal spike properties were also similar for both groups (WT, $n=19$; GDNF-OE, $n=28$ ), including the following: (1) amplitude (GDNF-OE, $71.1 \pm 1.5 \mathrm{mV}$; WT, $70.1 \pm 3.5 \mathrm{mV})$; (2) action potential duration at half-amplitude (GDNF-OE, $2.99 \pm$

Figure 1. Examples of intracellular recording and immunostaining of cutaneous (-fiber somata in WT mice. $\boldsymbol{a}$, Somal action potential and first derivative from a (-polymodal nociceptor. $\boldsymbol{b}$, The cell in $\boldsymbol{a}$ stained positively for IB4 (red) and P2X (blue). $\boldsymbol{C}$, Somal action potential and first derivative of a C-mechanonociceptor. $\boldsymbol{d}$, This cell was IB4 negative (red) and CGRP positive (blue).

vitrogen) to remove genomic DNA, and then $1 \mu \mathrm{g}$ was reverse transcribed using Superscript II reverse transcriptase (Invitrogen). Routine control reactions included PCR reactions on DNased RNA [without reverse transcriptase (RT)], and reactions were run without templates to test for contamination. Two methods of PCR amplification were used. To measure transient receptor potentials TRPV1, TRPV2, TRPV3, and TRPV4 transcripts, SYBR green-labeled PCR amplification was performed as described previously (Molliver et al., 2005). An Applied Biosystems (Foster City, CA) real-time thermal cycler controlled by a Dell Latitude laptop computer running ABI Prism 7000 SDS software was used. Twenty nanograms of cDNA template were added to $50 \mu$ reaction
$0.1 \mathrm{~ms}$; WT, $2.67 \pm 0.32 \mathrm{~ms}$ ); (3) afterhyperpolarization amplitude (GDNF-OE, $17.7 \pm 0.6 \mathrm{mV}$; WT, $17.1 \pm 0.3 \mathrm{mV}$ ); and (4) afterhyperpolarization duration at half-amplitude (GDNF-OE, $13.6 \pm 0.7 \mathrm{~ms}$; WT, $12.2 \pm 0.1 \mathrm{~ms}$ ). All values here and below are listed as means \pm SEM. Statistical analysis (two-tailed $t$ test) of the resting membrane potential and listed somal spike properties from WT and GDNF-OE mice revealed that they were not statistically different. These data show that constitutively enhanced levels of GDNF in the skin did not cause a significant change in cutaneous C-fiber somal AP properties. 


\section{Effects of GDNF-OE on}

anatomical properties

After physiological characterization in the intracellular experiments, cells were iontophoretically injected with NB to allow visualization of the neuronal somata (Figs. 1-4) and, in some instances, the central terminations in the spinal cord (Figs. 3, 4). In preparations from WT mice (Figs. 1, 2), immunohistochemical analysis revealed that $68 \%$ (11 of 16) of the somata of cutaneous C-fibers bound the lectin IB4. Of neurons examined with combined IB4 and antisera for the ATP receptor $\mathrm{P}_{2} \mathrm{X}_{3}$ (Jahr and Jessell, 1983; Chen et al., 1995), $64 \%$ (7 of 11) stained positively for both (Fig. 1b). The remaining eight cells were reacted with IB4 and primary antisera for CGRP, which showed that 25\% (2 of 8 ) were CGRP positive (Fig. 1d). None were found to bind IB4 and stain positively for CGRP (Fig. 2b).

From GDNF-OE transgenic ganglia (Figs. 3, 4), we recovered the somata of 20 characterized C-fiber nociceptors. All 20 cells were positively labeled with the IB4 lectin, and, of these, 13 were also reacted with antisera for $\mathrm{P}_{2} \mathrm{X}_{3}$, with $10(77 \%)$ showing positive staining for both (Fig. 3b). Seven IB4-labeled somata were also reacted with antisera for CGRP (Fig. 4). Only one of seven IB4-labeled somata tested (14\%) was CGRP positive (data not shown).

Examination of the central projections of individual C-fiber nociceptive neurons in GDNF-OE $(n=6)$ and WT $(n=5)$ mice revealed that, in general, the central projections of these cutaneous primary sensory neurons were very similar to those described previously by Sugiura and colleagues and in previous studies from this laboratory (Sugiura et al., 1986, 1989; Woodbury et al., 2001, 2004). Both WT (data not shown) and GDNF-OE C-polymodal fibers projected extensively in lamina $\mathrm{I}$ and $\mathrm{II}_{\mathrm{o}}$ and formed dense "nest-like" terminal fields (Figs. 3, 4). Although the focus of the terminal fields of individual fibers varied slightly, there was no obvious difference between the projections of transgenic and wild-type fibers. It is important to note that, in agreement with our previous findings (Woodbury et al., 2004), these results demonstrate that cutaneous afferents with cell bodies that stained positively for IB4 and P2 $\mathrm{X}_{3}$ (Fig. $3 b)$ or were IB4 positive and CGRP negative (Fig. $4 a$ ) can give rise to extensive projections in laminas I and $\mathrm{II}_{\mathrm{o}}$.

\section{Effects on peripheral response properties}

The immunostaining results from the intracellular recordings of C-fiber nociceptive neurons in GDNF-OE preparations, i.e., 20

a.

e.

f. stimulus.
C-polymodal nociceptor
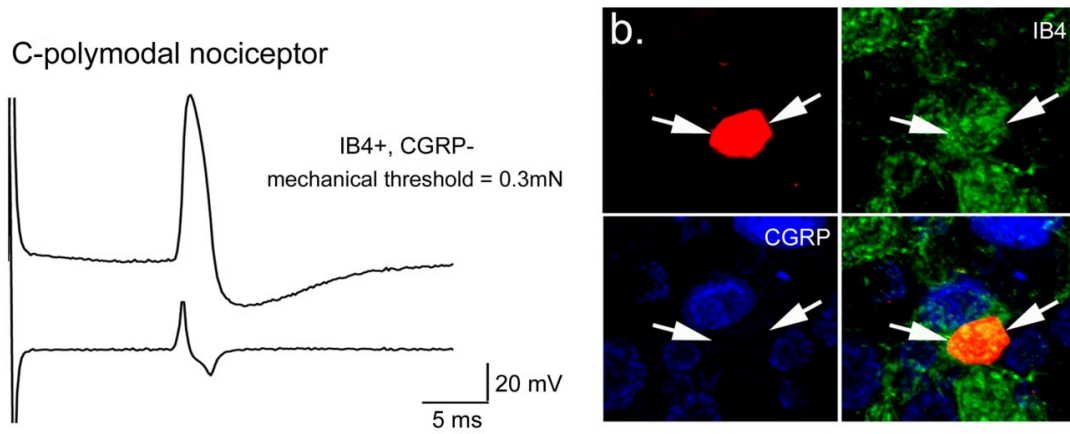

C. C-low threshold mechanoreceptor + cool
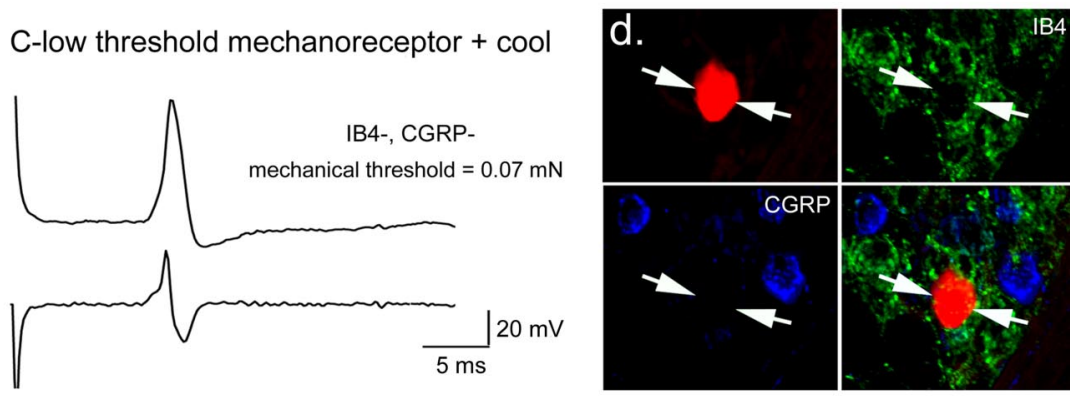
C-polymodal nociceptor
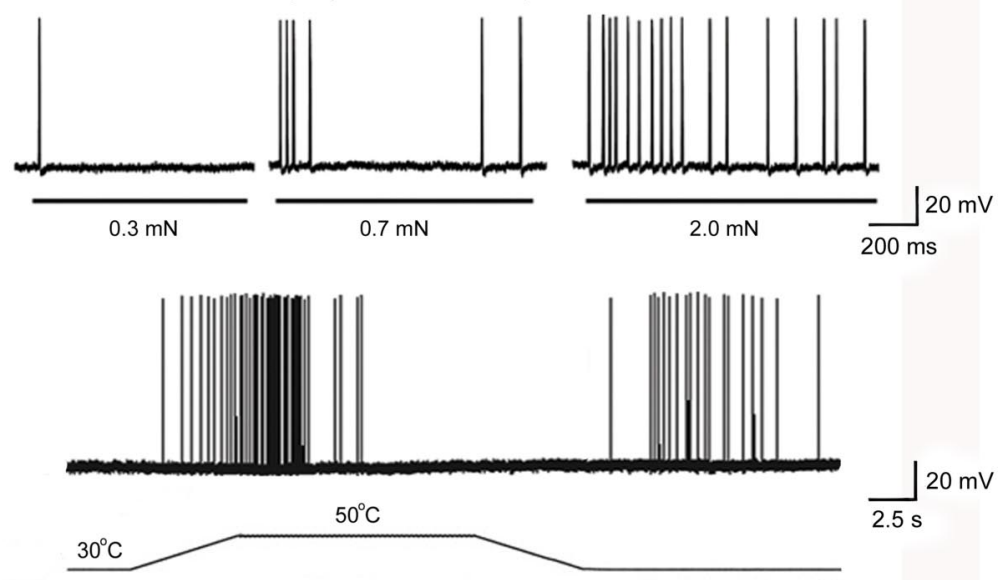
C-low threshold mechanoreceptor + cool

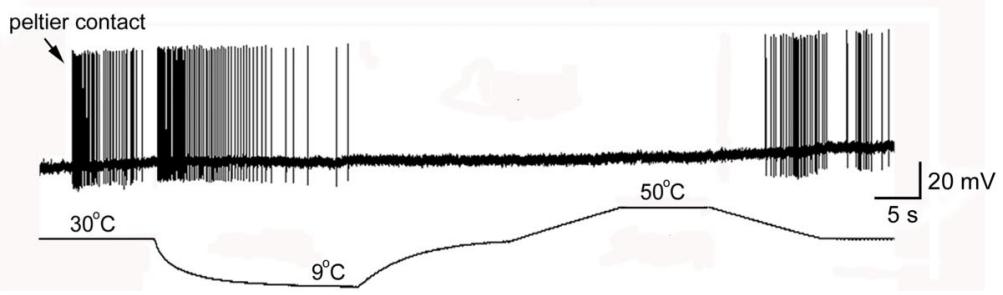

Figure 2. Examples of two $\mathrm{C}$-fiber somata recorded from and labeled in a WT preparation. $\boldsymbol{a}$, The broad inflected somal action potential and first derivative from a cell characterized as a C-polymodal nociceptor. $\boldsymbol{b}$, The sensory neuron in $\boldsymbol{a}$ stained with NB (red) was found to be IB4 (green) positive and GRP (blue) negative. Overlap of triple labeling is shown in the bottom right panel. c, This neuron was characterized as a CLTM that also responded to cooling of the skin. It had a relatively brief inflected somal action potential. $\boldsymbol{d}$, The NB-labeled cell shown in $\boldsymbol{c}$ was negative for IB4 (green) and CGRP (blue). $\boldsymbol{e}$, Examples of the mechanical and heat responses of a C-polymodal nociceptor that was IB4 positive and CGRP negative. $\boldsymbol{f}$, Example of the mechanical and thermal response properties of a CLTMR that was negative for IB4 and CGRP. Note that these fibers exhibited after discharge after the heat

of 20 cells were IB4 positive, indicated that we were examining a homogeneous population of fibers. In a previous report on this transgenic line (Zwick et al., 2002), it was found that cells binding IB4 were hypertrophied compared with those in wild-type mice 


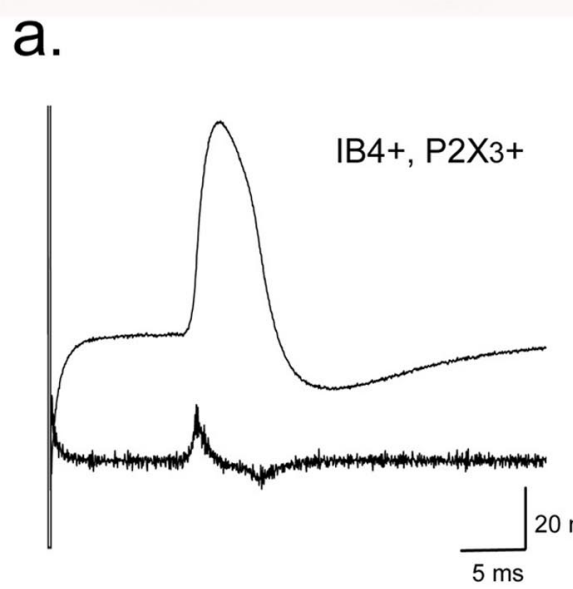

mechanical
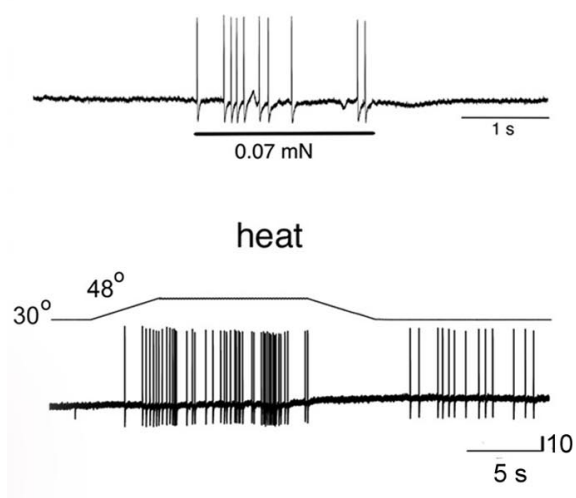
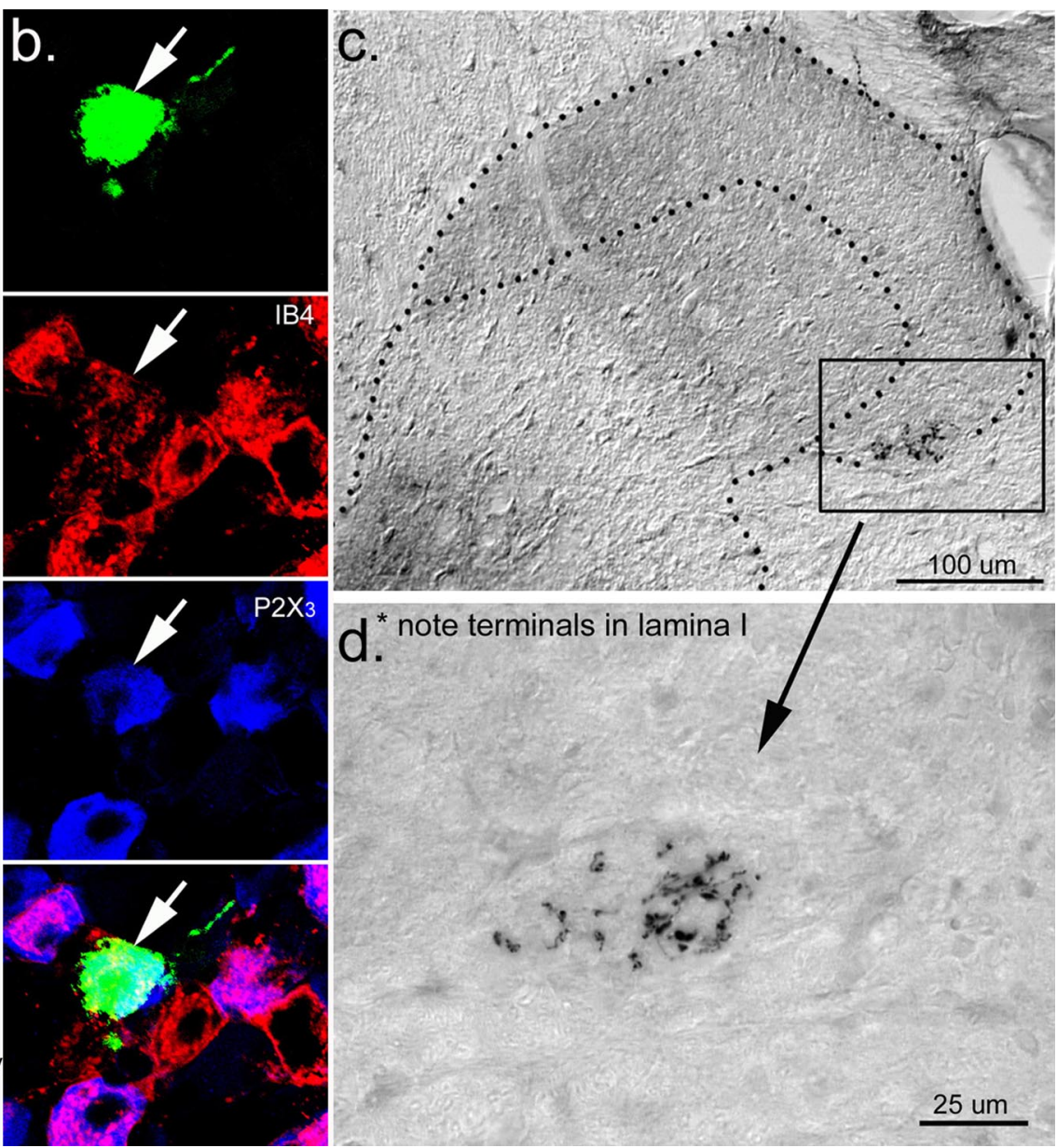

Figure 3. Example of the most commonly observed C-fiber comprehensive phenotype in the GDNF-0E preparations. $a$, This sensory neuron had a broad inflected somal action potential and was characterized as a low-threshold mechanoreceptor by its vigorous response to a very small force applied using a calibrated ( $0.07 \mathrm{mN})$ von Frey filament. It also responded vigorously to noxious heating of the skin, which is characteristic of a heat nociceptor. $\boldsymbol{b}$, Neuron characterized in $\boldsymbol{a}$ was IB4 (red) and P2X (blue) positive. The bottom panel shows triple-label overlap. $\boldsymbol{c}$, Dorsal horn termination of C-fiber shown in $\boldsymbol{a}$ and $\boldsymbol{b}$. Dotted lines show the outline of the dorsal horn and the boundary between laminas II and III. $\boldsymbol{d}$, High-power view to show fiber arborization in laminas I-II outer. Note that this fiber exhibited after discharge after the heat stimulus.

(see Fig. 6). Together, these findings suggest that the intracellular recordings may have been biased toward the larger (IB4-positive) cells in the GDNF-OE mice.

To counter this potential bias, we used fiber teasing techniques. Additional C-fiber response properties in WT $(n=12)$ and GDNF-OE $(n=10)$ mice were analyzed using this approach. For all measurements made, i.e., conduction velocity and thermal response properties, the results using the two different preparations were analyzed and found to be statistically indistinguishable within WT and OE groups. For example, of the 19 WT C-fiber neurons recorded intracellularly, only one had a mechanical threshold below $0.07 \mathrm{mN}$. The mean threshold of all fibers tested was $0.87 \pm 0.16 \mathrm{mN}$. For the $12 \mathrm{WT} C$-fibers recorded using fiber teasing methods, none had thresholds $<0.3 \mathrm{mN}$, and the mean was $0.90 \pm 0.19 \mathrm{mN}$. The $28 \mathrm{C}$-fiber neurons recorded intracellularly from GDNF-OE mice had a mean mechanical threshold of $0.31 \pm 0.06 \mathrm{mN}$, with 14 having mechanical thresholds of $\leq 0.07$ $\mathrm{mN}$. Of the 10 recorded using fiber teasing, the mean was $0.34 \pm$ $0.09 \mathrm{mN}$, and five had thresholds $\leq 0.07 \mathrm{mN}$. Thus, results from the two preparations were combined for additional analysis of the peripheral response properties.

The combined analysis indicates that $\mathrm{C}$-fibers recorded in the GDNF-OE preparations had significantly faster conduction velocities $(0.75 \pm 0.2 \mathrm{~m} / \mathrm{s} ; n=38$; range, $0.49-0.97 \mathrm{~m} / \mathrm{s})$ than those in wild-type preparations $(0.62 \pm 0.03 \mathrm{~m} / \mathrm{s} ; n=31$; range, 0.35 $0.79 \mathrm{~m} / \mathrm{s} ; p<0.01$, two-tailed $t$ test), likely reflecting a hypertrophy of unmyelinated peripheral axons in response to the excess GDNF level (Zwick et al., 2002). It should also be noted that this increase in unmyelinated fiber velocity was not caused by slowing of myelinated fibers because they also exhibited hypertrophy in these mice (Zwick et al., 2002). In addition, C-fibers in GDNF-OE mice had significantly lower mechanical thresholds $(0.33 \pm 0.08 \mathrm{mN} ; n=34)$ than those in WT mice $(0.88 \pm 0.17$ $\mathrm{mN} ; n=31 ; p<0.01$, two-tailed test) (Fig. $5 a$ ). If the comparison was limited to those cells recovered and found to bind IB4, the GDNF-OE mechanical thresholds $(0.25 \pm 0.06 \mathrm{mN} ; n=20)$ were also significantly lower than those for WT afferents $(0.68 \pm 0.25$ $\mathrm{mN} ; n=11 ; p<0.01$, two-tailed test). Although this is a relatively small number of stained cells, it shows that the overall decrease is most likely caused by changes in the GDNF-sensitive afferent population.

As stated above, in WT mice, we found only one C-fiber that had a mechanical threshold of $\leq 0.07 \mathrm{mN}$, and this fiber also responded to innocuous cooling of the skin and did not bind IB4 or CGRP (Fig. 2f), which is indicative of a CLTMR (Bessou et al., 1971). Therefore, in this mouse back skin preparation, C-fibers with mechanical thresholds $\geq 0.3 \mathrm{mN}$ were considered HTMRs, and those with thresholds $<0.3 \mathrm{mN}$ were LTMRs (Fig. 5). 
Many (20 of 38) of the fibers in the GDNF-OE mice were characterized as LTMRs $(\leq 0.07 \mathrm{mN})$. All 20 of these LTMRs also responded to noxious heating of the skin (Fig. 3a). These features represent a novel sensory neuron phenotype because they are unlikely to be CLTMRs because CLTMRs typically do not exhibit heat sensitivity (Bessou et al., 1971). It had been suggested previously that CLTMRs have significantly briefer somal action potentials than their HTMR counterparts (Djouhri et al., 1998). We therefore examined the relationship between spike duration and mechanical thresholds across the population of C-fibers from WT and GDNF-OE mice (Fig. $5 d$ ). Whereas the one CLTMR from WT mice did have a relatively brief AP (Figs. $2 c, 5 d$ ), LTMR fibers recorded in GDNF-OE mice had AP potentials durations that were not different from those of HTMR (polymodal nociceptors) in WT mice. In addition, there was no difference in AP duration between LTMRs and HTMRs (polymodal nociceptors) in the GDNF-OE mice.

Whereas we only recorded and recovered one CLTMR in WT littermates, we recovered the somata of five C-fibers classified as CLTMRs in additional studies, with two in the same genetic background as the GDNF-OE mice $(\mathrm{B} 6 / \mathrm{C} 3 \mathrm{H})$ and three from a different mouse strain (Swiss Webster). These afferent fibers were very similar in their characteristics. They responded vigorously to application of a $0.07 \mathrm{mN}$ von Frey filament and also responded to innocuous cooling of the skin (Fig. 2f). In all cases, these cells did not respond to a heat ramp and did not bind IB4 or stain positively for CGRP (zero of five) (Fig. $2 d$ ). Although on average these CLTMR fibers from nonlittermate mice had briefer AP durations, they were not significantly different from those characterized as HTMR fibers in WT mice. However, it should be noted that this negative result may be the result of the small number of these CLTMRs recorded and inclusion of data from different mouse strains.

Overall thermal testing revealed that, in WT mice, $81 \%$ (21 of 26) of the C-fibers innervating back skin responded to noxious heating $\left(48-52^{\circ} \mathrm{C}\right)$ (Fig. $2 e$ ). A significantly higher percentage (97\%; 35 of 36) of C-fibers were heat sensitive in GDNF-OE mice (Fig. $3 a)\left(\chi^{2}\right.$ test, $\left.p<0.01\right)$ (Fig. 5b). However, both heat threshold and heat sensitivity were unchanged (threshold, GDNF-OE, $42.3 \pm 0.6^{\circ} \mathrm{C}, n=21$; WT, $41.5 \pm 7.9^{\circ} \mathrm{C}, n=35$; firing frequency at $48^{\circ} \mathrm{C}$, GDNF-OE, $1.84 \pm 0.3$ spikes $/ \mathrm{s}, n=21$; WT, $1.84 \pm 0.48$ spikes/s; $n=35$ ). Additional analysis revealed that GDNF-OE C-fibers with very low mechanical thresholds $(\leq 0.07 \mathrm{mN})$ had heat-evoked responses that were indistinguishable from those with higher mechanical thresholds in WT or GDNF-OE mice (Fig. 5c).

The majority of C-fibers (97\%) recorded in GDNF-OE mice responded to both mechanical and thermal stimulation and were therefore most likely polymodal nociceptors. To test this possibility, we evaluated the response of five of these cells, including three that had mechanical thresholds $\leq 0.07 \mathrm{mN}$ (LTMRs), to dilute acid $(0.2 \mathrm{M} \mathrm{HCl})$ applied to the receptive field. All five responded to the acid and stained positively for IB4 and $\mathrm{P} 2 \mathrm{X}_{3}$, supporting the classification of these as polymodal nociceptors.

Ion channel expression in DRG of GDNF-OE transgenic mice The enhanced mechanical sensitivity exhibited by C-fibers of GDNF-OE animals raised the possibility that expression of ion channel proteins that are thought to underlie thermal and mechanical sensitivity was modulated in neurons responsive to GDNF. To test this possibility, we used RT-PCR assays to measure the relative expression level of transcripts encoding proteins in the ASICs and TRPs families. Comparative analysis of transcripts encoding ASIC1, ASIC2a, ASIC2b, and ASIC3 from lumbar level (L3, L4, and L5) DRG showed no difference in ASIC1 or ASIC3 mRNA level between wild-type and GDNF-OE ganglia (Table 2). However, ASIC2a mRNA was 3.28-fold higher $(p<$ $0.005)$ than the wild-type level, whereas ASIC2b levels were increased 1.38-fold ( $p<0.05$ ).

To determine whether the increased mRNA expression resulted in increased levels of ASIC2 protein, thoracic DRG sections from four WT and four GDNF-OE mice were immunolabeled using an antibody that detects both ASIC2a and ASIC2b. Examination of these ganglia using confocal microscopy showed an apparent increase in the intensity of labeling of ASIC2 in the small neuron population (Fig. $6 a, d$ ). Although small cells ap- 

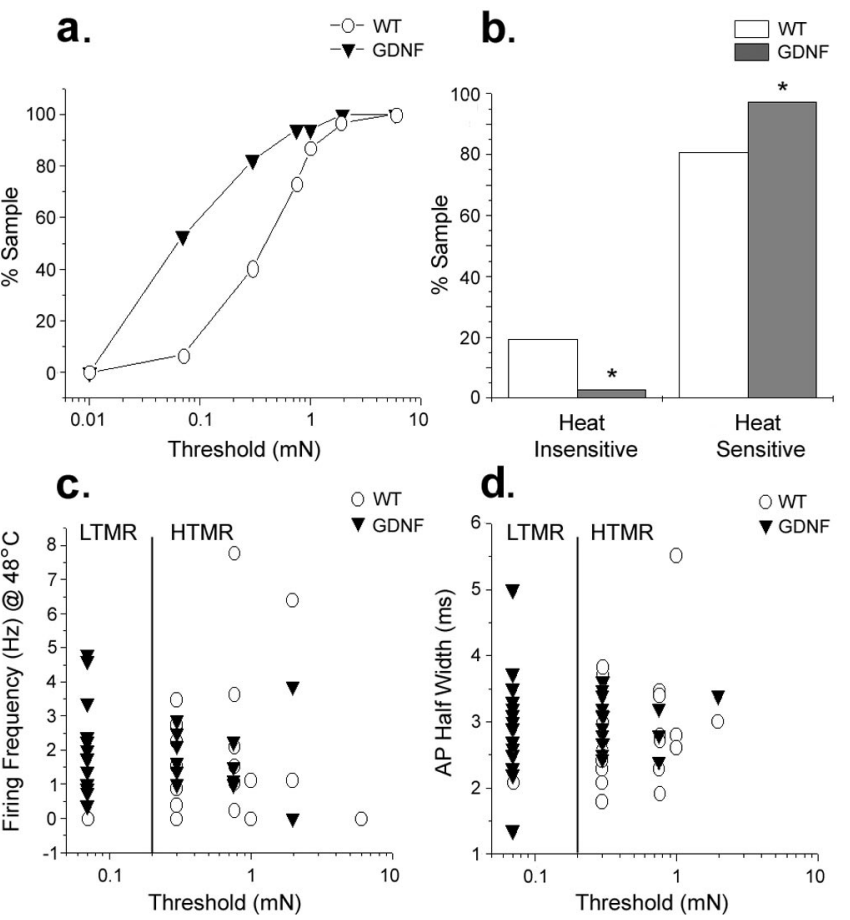

d.

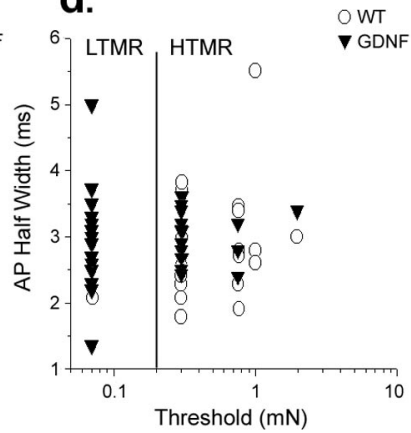

Figure 5. Summary of physiological data. $\boldsymbol{a}$, Cumulative sum plot showing a significant decrease in mechanical threshold of $C$-fibers in GDNF-0E mice $(n=34)$ compared with WT mice $(n=31) . \boldsymbol{b}$, Bar graph depicting the significant increase ${ }^{*} p<0.01, \chi^{2}$ test) in the number of C-fibers responding to heating of the skin in GDNF-OE mice $(n=36)$ compared with WT mice $(n=31)$. More than $97 \%$ of C-fibers in transgenic DRG responded to heat compared with $81 \%$ in WT mice. c, Scatter plot showing the relationship between heat sensitivity and mechanical threshold for C-fibers in WT and GDNF-OE mice. $\boldsymbol{d}$, Scatter plot showing the relationship between somal action potential duration (at half-amplitude) and mechanical threshold.

peared to have greater labeling, the intensity of labeling in largediameter sensory neurons was relatively unchanged. In addition, double labeling with IB4 (Fig. 6b,e) showed that this increase was predominantly, but not exclusively, in the putative GDNFresponsive IB4 population (Fig. $6 c, f$ ). This increase in ASIC2 staining was also observed in the peripheral dorsal cutaneous nerves near their entry into the skin (Fig. $6 g, h$ ). This suggests that the increase in mRNA found in the DRG results in an increase in ASIC2 protein transported into the periphery. Although the increased immunoreactivity was not specific to a single population of fibers, it was very clear that the population of sensory neurons showing the increased mechanical sensitivity (i.e., IB4-positive cells) were among those fibers exhibiting enhanced ASIC2 immunolabeling in the GDNF-OE ganglia.

Nearly all C-fibers (97\%) recorded from in GDNF-OE ganglia exhibited thermal sensitivity. To test whether this increase in heat-responsive C-fibers correlated with enhanced expression of thermal-responsive ion channels, the relative level of TRPV1, TRPV2, TRPV3, and TRPV4 transcripts in WT and GDNF-OE DRG were assayed (Table 2). This analysis showed a modest de- crease $(-1.47$-fold; $p=0.05)$ in the relative abundance of the TRPV1 channel, although no change in other TRPV transcript levels was detected. Two channels in the TRP family that are activated by cold (TRPA1 or ANKTM1) and cool (TRPM8) stimuli were also assayed (Peier et al., 2002; Story et al., 2003). Measure of the transcript level of these two genes showed a 1.49-fold increase in TRPA1 $(p<0.05)$ and a 1.47-fold decrease in TRPM8 $(p<0.005)$ in lumbar DRG of GDNF-OE animals (Table 2$)$.

\section{Discussion}

In this study, we examined the effects of enhanced levels of targetderived GDNF on the peripheral response properties of cutaneous C-fibers and expression of ASIC and TRP channel proteins in sensory neurons. Afferents from wild-type and GDNF-OE transgenic animals were characterized using an ex vivo preparation containing the skin, nerve, ganglia, and spinal cord. GDNF was found to significantly increase the mechanical sensitivity of cutaneous $\mathrm{C}$-fibers and the percentage of fibers that were responsive to noxious heat. After physiological characterization, afferents were labeled with Neurobiotin to determine their chemical phenotype and central projection pattern. The results show the appearance of a large population of IB4-positive C-fibers that exhibit a novel comprehensive phenotype in GDNF-OE mice, i.e., polymodal nociceptors (respond to noxious heat, are IB4 and $\mathrm{P}_{2} \mathrm{X}_{3}$ positive, and project to dorsal horn laminas I and II) that respond briskly to innocuous touch. There are two plausible explanations for these findings. (1) Target overexpression of GDNF during development increases the number of non-nociceptive CLTMRs that lose sensitivity to cooling and develop heat and acid sensitivity. (2) The increased level of GDNF results in reduction of mechanical thresholds of C-polymodal nociceptors.

The first hypothesis is supported by a previous study showing that CLTMRs innervating the ear skin of rabbits exhibit weak heat responses (Shea and Perl, 1985). However, all of the CLTMRs examined in WT and other control mouse strains responded to cooling but not to heat. Importantly, they did not bind IB4, suggesting that they lack sensitivity to GDNF (Bennett et al., 1998). Strong support for the second hypothesis comes from analysis of somal spike parameters, chemical phenotype, and central projection patterns. In WT mice and guinea pigs (Djouhri et al., 1998), CLTMRs have relatively narrow action potentials and do not immunolabel for nociceptive markers (e.g., IB4 and CGRP) (Fig. 2) and, unlike the central projections seen here, project extensively to deeper parts of lamina II as seen in guinea pig (Sugiura, 1986). The central anatomy and the unchanged somal action potential properties of the IB4, $\mathrm{P}_{2} \mathrm{X}_{3}$ positive C-fibers in GDNF-OE mice strongly suggest that the second hypothesis, that proposes increased levels of cutaneous GDNF lowers mechanical thresholds of GDNF-sensitive polymodal nociceptors, is most consistent with the data.

A previous report on these animals showed that they did not exhibit increased sensitivity to mechanical stimuli (Zwick et al., 2002). However, the pronounced increase in sensitivity of the polymodal nociceptors seen here suggests that alterations in the

Table 2. Relative abundance of mRNAs associated with channels that mediate mechanical and thermal sensation in lumbar DRG of wild-type and GDNF-0E animals

\begin{tabular}{|c|c|c|c|c|c|c|c|c|c|c|}
\hline & ASIC1 & $\mathrm{ASIC} 2 \mathrm{~A}$ & $A S I C 2 B$ & ASIC3 & TRPV1 & TRPV2 & TRPV3 & TRPV4 & TRPA1 & TRPM8 \\
\hline Wild type & $1.16 \pm 0.11$ & $0.47 \pm 0.21$ & $0.85 \pm 0.04$ & $0.82 \pm 0.10$ & $4.48 \pm 0.26$ & $5.42 \pm 0.33$ & $15.06 \pm 0.49$ & $11.24 \pm 0.39$ & $1.12 \pm 0.02$ & $0.96 \pm 0.01$ \\
\hline GDNF-OE & $1.04 \pm 0.10$ & $1.54 \pm 0.27$ & $1.18 \pm 0.05$ & $0.96 \pm 0.09$ & $5.04 \pm 0.43$ & $5.62 \pm 0.46$ & $15.41 \pm 0.53$ & $11.61 \pm 0.49$ & $1.66 \pm 0.15$ & $0.65 \pm 0.02$ \\
\hline Fold change & 1.11 & $+3.28^{* *}$ & $+1.38^{*}$ & 1.17 & $-1.47^{*}$ & -1.14 & -1.27 & -1.28 & $+1.49^{*}$ & $-1.47^{* *}$ \\
\hline
\end{tabular}

RNA extracted from lumbar DRGs from four WT and five GDNF-0E animals was used to measure relative expression of ASICs, TRPA1, and TRPM8 in PCR reactions spiked with [32P]dCTP and quantified using a Phosphorimager. Values are relative intensity measures \pm SEM. To determine relative expression of TRPV channels in GDNF-OE lumbar DRG, RNA was extracted from ganglia isolated from three WT and three GDNF-0E animals and analyzed in triplicate using SYBR green-based real-time PCR assays. Shown are normalized $C_{\mathrm{T}}$ values relative to GAPDH, calculated relative fold change $\left(2^{-\Delta \mathrm{CT}}\right.$; see Materials and Methods). ${ }^{*} p \leq 0.05$, ${ }^{* *} p \leq 0.005$, significant change in transcript abundance. 
function of central networks may have compensated for this increased afferent activity.

To determine possible mechanisms that underlie the functional changes in C-fiber phenotype in GDNF-OE mice, we tested the hypothesis that enhanced GDNF signaling through the Ret and GFR $\alpha 1$ receptor complex may have altered expression of ion channels associated with transmission of mechanical and/or thermal stimuli. The expression of several members of the TRP and ASIC family of ion channels were examined because recent evidence supports a role for these proteins in thermal and/or mechanical transduction (Caterina et al., 2000; Caterina and Julius, 2001; Welsh et al., 2002; Jordt et al., 2003). Interestingly, although there was an increase in the percentage of heat responsive C-fibers, TRPV1 channel expression in GDNF-OE ganglia decreased (1.47-fold). TRPV1 responds to noxious heat in heterologous expression systems and is required for inflammation-induced heat hypersensitivity (Caterina et al., 1997; Davis et al., 2000; Moriyama et al., 2003). However, GDNF-OE mice exhibit an increase in the percentage of IB4-positive neurons that, in mouse, are typically TRPV1 negative (Zwick et al., 2002). This increase in IB4positive/TRPV1-negative neurons in GDNF-OE mice would decrease the prevalence of afferents expressing TRPV1 and thereby decrease the amount of TRPV1/ ganglion. An increase in TRPA1 expression also occurred in GDNF-OE ganglia. This channel is postulated to have an important role in signaling noxious cold in sensory neurons (Story et al., 2003). However, recent evidence suggests that TRPA1 may also have a role in mechanosensation (Corey et al., 2004). Thus, it could contribute to the increased mechanical sensitivity of C-fibers found in GDNF-OE afferents. Also of interest was the decrease in TRPM8 mRNA in the DRG of GDNF-OE mice. TRPM8 responds to menthol and cooling (McKemy et al., 2002; Peier et al., 2002). Its reduction provides some support for the above hypothesis 1 that predicts that CLMTR fibers lose sensitivity to cooling of the skin. However, the significant but modest increase in TRPA1 and reduction in TRPV 1 and TRPM 8 could simply reflect a shift in cell populations such that the $50 \%$ increase in neurons binding IB4, e.g., polymodal nociceptors (Zwick et al., 2002), was at the expense of other cell types such as the CLTMR population.

Mechanisms responsible for the observed reduction in mechanical thresholds cannot be easily explained by changes in the relative numbers of specific subsets of sensory neurons. The increase in the ASIC2 splice variants ASIC2a and ASIC2b does, however, provide a possible mechanism. Previous studies have suggested that these channels have a role in mechanosensation. For example, Price et al. (2000) reported that rapidly adapting myelinated low-threshold mechanoreceptors had diminished mechanical sensitivity in mice lacking ASIC2. In addition,
Garcia-Anoveros et al. (2001) demonstrated that ASIC2a was localized to afferent fibers innervating cutaneous structures associated with innocuous myelinated low-threshold mechanoreceptors, such as Merkel cell complexes and hair follicles. Thus, it is plausible that an increase in ASIC channel expression by elevated GDNF levels underlies the enhanced mechanosensitivity of normally nociceptive afferents. A recent study has also suggested that growth factors affect ASIC channel expression. McIlwrath et al. (2005) showed that expression of ASIC2 in cultured neurons is regulated by brain-derived neurotrophic factor (BDNF). They postulated that depletion of BDNF in $\mathrm{BDNF}^{-1-}$ animals caused decreased expression of ASIC2 and subsequent loss in sensitivity of medium-to-large diameter slowly adapting mechanoreceptors.

It has also been suggested that individual ASIC channels (i.e., ASIC1, ASIC2, and ASIC3) are coexpressed and are capable of forming heteromeric ion channels, and that different ratios of specific channel subunits (e.g., ASIC1/ASIC2 or ASIC2/ASIC3) influence channel kinetics in response to protons (Benson et al., 2002; Xie et al., 2002). A similar scheme for mechanotransduction has also been proposed and supported by studies of ASIC3 knock-out mice that showed that $\mathrm{A} \beta$ rapidly adapting lowthreshold mechanoreceptors exhibited increased mechanical sensitivity (Price et al., 2001; Lewin and Moshourab, 2004). One 
interpretation of these findings would be that loss of ASIC3 would increase the contribution of ASIC2 in heteromeric ion channels, and that this alteration increases mechanical sensitivity.

Here we found a pronounced increase in ASIC2 expression in IB4-positive afferents of GDNF-OE mice. Although this increase was not specific to the IB4 population, it does suggest these GDNF-sensitive C-fibers have increased levels of ASIC2a and/or ASIC2b arranged in heteromeric channel complexes. Thus, increased mechanosensitivity exhibited by GDNF-responsive C-fibers could be attributable, at least in part, to enhanced expression of ASIC2. It is not clear whether this increased expression is de novo or whether these cells normally contain low levels of this channel that become increased by enhanced GDNF levels. However, given that increased ASIC2 staining was not specific to the IB4 population, the increased expression could be an indirect effect.

Although these data are compelling, it should be noted that a recent study of mechanosensory transduction in cultured DRG neurons showed that neurons lacking ASIC2 and/or ASIC3 exhibited a normal response to mechanical stimulation when applied to the cell body (Drew et al., 2004). These studies suggest that another channel important for mechanosensory function exists in DRG neurons. However, the functional relevance of the ASIC family of channels may only be realized in the context of the appropriate environment in which the skin, nerve, and spinal cord connections are intact.

In summary, it was shown previously that constitutive overexpression of GDNF in the skin results in a significant increase in the number of IB4-positive cells in the DRG. Here we show that this excess GDNF causes a dramatic decrease in the mechanical thresholds of polymodal nociceptors with no change in their response to heat. This reduced mechanical sensitivity may be attributable to increased expression of the ASIC2 ion channel. Thus, sustained treatment with GDNF could be problematic and lead to sensory abnormalities. Interestingly, cutaneous sensory abnormalities (e.g., parenthesias) were common in patients receiving intracerebroventricular GDNF as a treatment for Parkinson's disease (Nutt et al., 2003). However, it should be noted that a $15 \mathrm{~d}$ intrathecal application of high concentrations $(12 \mu \mathrm{g} / \mathrm{d})$ of GDNF caused a reduction in neuropathic pain after peripheral nerve injury (Boucher et al., 2000). Conversely, injection of an antibody to GDNF decreased hyperalgesia after complete Freund's adjuvant injection (Fang et al., 2003). Clearly, the route of administration and experimental model are critical factors in the evaluation of GDNF action in the sensory system.

\section{References}

Airaksinen MS, Saarma M (2002) The GDNF family: signalling, biological functions and therapeutic value. Nat Rev Neurosci 3:383-394.

Albers KM, Wright DE, Davis BM (1994) Overexpression of nerve growth factor in epidermis of transgenic mice causes hypertrophy of the peripheral nervous system. J Neurosci 14:1422-1432.

Baloh RH, Enomoto H, Johnson Jr EM, Milbrandt J (2000) The GDNF family ligands and receptors: implications for neural development. Curr Opin Neurobiol 10:103-110.

Bennett DL, Michael GJ, Ramachandran N, Munson JB, Averill S, Yan Q, McMahon SB, Priestley JV (1998) A distinct subgroup of small DRG cells express GDNF receptor components and GDNF is protective for these neurons after nerve injury. J Neurosci 18:3059-3072.

Benson CJ, Xie J, Wemmie JA, Price MP, Henss JM, Welsh MJ, Snyder PM (2002) Heteromultimers of DEG/ENaC subunits form $\mathrm{H}^{+}$-gated channels in mouse sensory neurons. Proc Natl Acad Sci USA 99:2338-2343.

Bessou P, Burgess PR, Perl ER, Taylor CB (1971) Dynamic properties of mechanoreceptors with unmyelinated (C) fibers. J Neurophysiol 34:116-131.

Boucher TJ, Okuse K, Bennett DL, Munson JB, Wood JN, McMahon SB (2000) Potent analgesic effects of GDNF in neuropathic pain states. Science 290:124-127.

Caterina MJ, Julius D (2001) The vanilloid receptor: a molecular gateway to the pain pathway. Annu Rev Neurosci 24:487-517.

Caterina MJ, Schumacher MA, Tominaga M, Rosen TA, Levine JD, Julius D (1997) The capsaicin receptor: a heat-activated ion channel in the pain pathway. Nature 389:816-824.

Caterina MJ, Leffler A, Malmberg AB, Martin WJ, Trafton J, Petersen-Zeitz KR, Koltzenburg M, Basbaum AI, Julius D (2000) Impaired nociception and pain sensation in mice lacking the capsaicin receptor. Science 288:306-313.

Chen CC, Akopian AN, Sivilotti L, Colquhoun D, Burnstock G, Wood JN (1995) A P2X purinoceptor expressed by a subset of sensory neurons. Nature 377:428-431.

Corey DP, Garcia-Anoveros J, Holt JR, Kwan KY, Lin SY, Vollrath MA, Amalfitano A, Cheung EL, Derfler BH, Duggan A, Geleoc GS, Gray PA, Hoffman MP, Rehm HL, Tamasauskas D, Zhang DS (2004) TRPA1 is a candidate for the mechanosensitive transduction channel of vertebrate hair cells. Nature 432:723-730.

Crowley C, Spencer SD, Nishimura MC, Chen KS, Pitts-Meek S, Armanini MP, Ling LH, MacMahon SB, Shelton DL, Levinson AD, Phillips HS (1994) Mice lacking nerve growth factor display perinatal loss of sensory and sympathetic neurons yet develop basal forebrain cholinergic neurons. Cell 76:1001-1011.

Davis JB, Gray J, Gunthorpe MJ, Hatcher JP, Davey PT, Overend P, Harries MH, Latcham J, Clapham C, Atkinson K, Hughes SA, Rance K, Grau E, Harper AJ, Pugh PL, Rogers DC, Bingham S, Randall A, Sheardown SA (2000) Vanilloid receptor-1 is essential for inflammatory thermal hyperalgesia. Nature 405:183-187.

Dirajlal S, Pauers LE, Stucky CL (2003) Differential response properties of $\mathrm{IB}(4)$-positive and -negative unmyelinated sensory neurons to protons and capsaicin. J Neurophysiol 89:513-524.

Djouhri L, Bleazard L, Lawson SN (1998) Association of somatic action potential shape with sensory receptive properties in guinea-pig dorsal root ganglion neurones. J Physiol (Lond) 513:857-872.

Drew LJ, Rohrer DK, Price MP, Blaver KE, Cockayne DA, Cesare P, Wood JN (2004) Acid-sensing ion channels ASIC2 and ASIC3 do not contribute to mechanically activated currents in mammalian sensory neurones. J Physiol (Lond) 556:691-710.

Fang M, Wang Y, He QH, Sun YX, Deng LB, Wang XM, Han JS (2003) Glial cell line-derived neurotrophic factor contributes to delayed inflammatory hyperalgesia in adjuvant rat pain model. Neuroscience 117:503-512.

Fjell J, Cummins TR, Fried K, Black JA, Waxman SG (1999) In vivo NGF deprivation reduces SNS expression and TTX-R sodium currents in IB4negative DRG neurons. J Neurophysiol 81:803-810.

Garcia-Anoveros J, Samad TA, Zuvela-Jelaska L, Woolf CJ, Corey DP (2001) Transport and localization of the $\mathrm{DEG} / \mathrm{ENaC}$ ion channel $\mathrm{BNaCl} \alpha$ to peripheral mechanosensory terminals of dorsal root ganglia neurons. J Neurosci 21:2678-2686.

Gerke MB, Plenderleith MB (2001) Binding sites for the plant lectin Bandeiraea simplicifolia I-isolectin $\mathrm{B}(4)$ are expressed by nociceptive primary sensory neurones. Brain Res 911:101-104.

Guo A, Vulchanova L, Wang J, Li X, Elde R (1999) Immunocytochemical localization of the vanilloid receptor 1 (VR1): relationship to neuropeptides, the P2X3 purinoceptor and IB4 binding sites. Eur J Neurosci 11:946-958.

Jahr CE, Jessell TM (1983) ATP excites a subpopulation of rat dorsal horn neurones. Nature 304:730-733.

Jordt SE, McKemy DD, Julius D (2003) Lessons from peppers and peppermint: the molecular logic of thermosensation. Curr Opin Neurobiol 13:487-492.

Kitchener PD, Wilson P, Snow PJ (1993) Selective labelling of primary sensory afferent terminals in lamina II of the dorsal horn by injection of Bandeiraea simplicifolia isolectin B4 into peripheral nerves. Neuroscience 54:545-551.

Koerber HR, Woodbury CJ (2002) Comprehensive phenotyping of sensory neurons using an ex vivo somatosensory system. Physiol Behav 77:589-594. 
Koltzenburg M (1999) The changing sensitivity in the life of the nociceptor. Pain [Suppl] 6:S93-S102.

Lewin GR, Moshourab R (2004) Mechanosensation and pain. J Neurobiol 61:30-44

Light AR, Perl ER (1979) Spinal termination of functionally identified primary afferent neurons with slowly conducting myelinated fibers. J Comp Neurol 186:133-150.

McIlwrath SL, Hu J, Anirudhan G, Shin JB, Lewin GR (2005) The sensory mechanotransduction ion channel ASIC2 (acid sensitive ion channel 2) is regulated by neurotrophin availability. Neuroscience 131:499-511.

McKemy DD, Neuhausser WM, Julius D (2002) Identification of a cold receptor reveals a general role for TRP channels in thermosensation. Nature 416:52-58.

Mendell LM, Albers KM, Davis BM (1999) Neurotrophins, nociceptors, and pain. Microsc Res Tech 45:252-261.

Molliver DC, Snider WD (1997) Nerve growth factor receptor TrkA is down-regulated during postnatal development by a subset of dorsal root ganglion neurons. J Comp Neurol 381:428-438.

Molliver DC, Wright DE, Leitner ML, Parsadanian AS, Doster K, Wen D, Yan Q, Snider WD (1997) IB4-binding DRG neurons switch from NGF to GDNF dependence in early postnatal life. Neuron 19:849-861.

Molliver DC, Lindsay J, Albers KM, Davis BM (2005) Overexpression of NGF or GDNF alters transcriptional plasticity evoked by inflammation. Pain 113:277-284.

Moore MW, Klein RD, Farinas I, Sauer H, Armanini M, Phillips H, Reichardt LF, Ryan AM, Carver-Moore K, Rosenthal A (1996) Renal and neuronal abnormalities in mice lacking GDNF. Nature 382:76-79.

Moriyama T, Iida T, Kobayashi K, Higashi T, Fukuoka T, Tsumura H, Leon C, Suzuki N, Inoue K, Gachet C, Noguchi K, Tominaga M (2003) Possible involvement of $\mathrm{P} 2 \mathrm{Y} 2$ metabotropic receptors in ATP-induced transient receptor potential vanilloid receptor 1-mediated thermal hypersensitivity. J Neurosci 23:6058-6062.

Nutt JG, Burchiel KJ, Comella CL, Jankovic J, Lang AE, Laws Jr ER, Lozano AM, Penn RD, Simpson Jr RK, Stacy M, Wooten GF (2003) Randomized, double-blind trial of glial cell line-derived neurotrophic factor (GDNF) in PD. Neurology 60:69-73.

Peier AM, Moqrich A, Hergarden AC, Reeve AJ, Andersson DA, Story GM, Earley TJ, Dragoni I, McIntyre P, Bevan S, Patapoutian A (2002) A TRP channel that senses cold stimuli and menthol. Cell 108:705-715.

Price MP, Lewin GR, Mcllwrath SL, Cheng C, Xie J, Heppenstall PA, Stucky CL, Mannsfeldt AG, Brennan TJ, Drummond HA, Qiao J, Benson CJ, Tarr DE, Hrstka RF, Yang B, Williamson RA, Welsh MJ (2000) The mammalian sodium channel $\mathrm{BNC1}$ is required for normal touch sensation. Nature 407:1007-1011.

Price MP, McIlwrath SL, Xie J, Cheng C, Qiao J, Tarr DE, Sluka KA, Brennan TJ, Lewin GR, Welsh MJ (2001) The DRASIC cation channel contributes to the detection of cutaneous touch and acid stimuli in mice. Neuron 32:1071-1083.

Rice FL, Albers KM, Davis BM, Silos-Santiago I, Wilkinson GA, LeMaster AM, Ernfors P, Smeyne RJ, Aldskogius H, Phillips HS, Barbacid M, DeChiara TM, Yancopoulos GD, Dunne CE, Fundin BT (1998) Differ- ential dependency of unmyelinated and A delta epidermal and upper dermal innervation on neurotrophins, trk receptors, and p75LNGFR. Dev Biol 198:57-81.

Shea VK, Perl ER (1985) Sensory receptors with unmyelinated (C) fibers innervating the skin of the rabbit's ear. J Neurophysiol 54:491-501.

Silverman JD, Kruger L (1988) Lectin and neuropeptide labeling of separate populations of dorsal root ganglion neurons and associated "nociceptor" thin axons in rat testis and cornea whole-mount preparations. Somatosens Res 5:259-267.

Snider WD, McMahon SB (1998) Tackling pain at the source: new ideas about nociceptors. Neuron 20:629-632.

Springer JE, Seeburger JL, He J, Gabrea A, Blankenhorn EP, Bergman LW (1995) cDNA sequence and differential mRNA regulation of two forms of glial cell line-derived neurotrophic factor in Schwann cells and rat skeletal muscle. Exp Neurol 131:47-52.

Story GM, Peier AM, Reeve AJ, Eid SR, Mosbacher J, Hricik TR, Earley TJ, Hergarden AC, Andersson DA, Hwang SW, McIntyre P, Jegla T, Bevan S, Patapoutian A (2003) ANKTM1, a TRP-like channel expressed in nociceptive neurons, is activated by cold temperatures. Cell 112:819-829.

Stucky CL, Lewin GR (1999) Isolectin B $B_{4}$-positive and -negative nociceptors are functionally distinct. J Neurosci 19:6497-6505.

Stucky CL, Koltzenburg M, Schneider M, Engle MG, Albers KM, Davis BM (1999) Overexpression of nerve growth factor in skin selectively affects the survival and functional properties of nociceptors. J Neurosci 19:8509-8516.

Sugiura Y, Lee CL, Perl ER (1986) Central projections of identified, unmyelinated (C) afferent fibers innervating mammalian skin. Science 234:358-361.

Sugiura Y, Terui N, Hosoya Y (1989) Difference in distribution of central terminals between visceral and somatic unmyelinated (C) primary afferent fibers. J Neurophysiol 62:834-840.

Welsh MJ, Price MP, Xie J (2002) Biochemical basis of touch perception: mechanosensory function of degenerin/epithelial $\mathrm{Na}^{+}$channels. J Biol Chem 277:2369-2372.

Woodbury CJ, Ritter AM, Koerber HR (2000) On the problem of lamination in the superficial dorsal horn of mammals: a reappraisal of the substantia gelatinosa in postnatal life. J Comp Neurol 417:88-102.

Woodbury CJ, Ritter AM, Koerber HR (2001) Central anatomy of individual rapidly adapting low-threshold mechanoreceptors innervating the "hairy" skin of newborn mice: early maturation of hair follicle afferents. J Comp Neurol 436:304-323.

Woodbury CJ, Zwick M, Wang S, Lawson JJ, Caterina MJ, Koltzenburg M, Albers KM, Koerber HR, Davis BM (2004) Nociceptors lacking TRPV1 and TRPV2 have normal heat responses. J Neurosci 24:6410-6415.

Xie J, Price MP, Berger AL, Welsh MJ (2002) DRASIC contributes to pHgated currents in large dorsal root ganglion sensory neurons by forming heteromultimeric channels. J Neurophysiol 87:2835-2843.

Zwick M, Davis BM, Woodbury CJ, Burkett JN, Koerber HR, Simpson JF, Albers KM (2002) Glial cell line-derived neurotrophic factor is a survival factor for isolectin B4-positive, but not vanilloid receptor 1-positive, neurons in the mouse. J Neurosci 22:4057-4065. 